\title{
DIGITALISASI PENDIDIKAN HUKUM DAN PROSPEKNYA PASCA PANDEMI COVID-19
}

\author{
Dian Rachmat Gumelar, Sri Sophiarani Dinnur \\ Prodi Ilmu Hukum, Prodi Ilmu Hukum \\ E-Mail:dianrgumelar@uinsgd.ac.id, sophiaranid@gmail.com
}

\begin{abstract}
This writing aims to describe the situation of digitizing legal education and its prospects during the Covid-19 pandemic. This paper aims to explain how the digitization of legal education can work in accordance with the era of the industrial revolution 4.0 and in the midst of the Covid-19 pandemic. The method used in this paper is the literature method, which relies on the use of reference books as study material to describe the theoretical framework as well as the limited space for movement during large-scale social restrictions. Utilization of the internet in education is not new. Many in various countries have used digitalization in education. However, in Indonesia before the pandemic its utilization was not optimal. The dependence of the community on the internet makes digitalization of education the only solution so that learning activities can still be carried out during the Covid-19 pandemic like this. There are facilities and infrastructure constraints that must be met in order to support learning activities. This writing was made to better understand the definition of digitalization of education, life in the era of the industrial revolution 4.0, the obstacles and challenges faced in this education digitization system, as well as the readiness of academic facilities and infrastructure in supporting the digitization of legal education.
\end{abstract}

Keywords: Industrial Revolution Era; Digitization of Education; The Covid-19 Pandemic.

\begin{abstract}
Abstrak
Penulisan ini bertujuan untuk mendeskripsikan situasi digitalisasi pendidikan hukum dan prosepeknya pada masa pandemi covid-19 ini. Tulisan ini bertujuan untuk menjelaskan bagaimana digitalisasi pendidikan hukum ini dapat berjalan sesuai dengan era revolusi industri 4.0 dan di tengah pandemi covid-19. Metode yang digunakan dalam penulisan ini adalah metode kepustakaan, yakni bertumpu kepada penggunaan referensi pustaka sebagai bahan kajian untuk menggambarkan kerangka teoritisnya seriring terbatasnya ruang gerak pada masa pembatasan sosial berskala besar. Pendayagunaan internet dalam pendidikan bukanlah hal yang baru. Banyak di berbagai negara sudah menggunakan digitalisasi dalam pendidikan. Hanya saja, di Indonesia pada masa sebelum pandemi pendayagunaanya belum optimal. Ketergantungan masyarakat pada internet membuat digitalisasi pendidikan ini menjadi satu-satunya solusi agar kegiatan pembelajaran tetap dapat dilaksanakan dimasa pandemi covid-19 seperti ini. Adapun kendala sarana dan prasarana yang harus dipenuhi dalam rangka menunjang kegiatan pembelajaran. Penulisan ini dibuat untuk lebih memahami kembali definisi dari digitalisasi pendidikan, kehidupan pada era revolusi industri 4.0, hambatan dan tantangan yang dihadapi dalam sistem digitalisasi pendidikan ini, serta kesiapan sarana dan prasarana akademik dalam mendukung digitalisasi pendidikan hukum.
\end{abstract}

Kata Kunci : Era Revolusi Industri; Digitalisasi Pendidikan; Pandemi Covid-19. 


\section{PENDAHULUAN}

Dewasa ini dunia digemparkan oleh suatu peristiwa wabah penyakit yang dapat mematikan banyak dari umat manusia dalam rentan waktu yang amat singkat. Penyakit yang bermula dari sebuah virus bernama corona atau disebut dengan istilah covid-19 ini mulai mewabah pada akhir bulan Desember tahun 2019 lalu di Kota Wuhan Provinsi Hubei Tiongkok, yang kemudian mewabah hingga ke seluruh dunia dalam rentan waktu yang amat singkat. Hingga pada tanggal 11 Maret 2020 WHO (World Health Organization) menetapkan wabah virus ini sebagai pandemi global.

Pandemi itu sendiri adalah penyakit yang menyebar secara luas atau global, dan umumnya menyerang langsung pada banyak orang. Sedangkan epidemi adalah sebuah istilah yang digunakan untuk mengetahui dan memeriksa peningkatan jumlah kasus penyakit tiba-tiba pada suatu populasi daerah tertentu. Pada dasarnya, istilah pandemi hanya untuk memperlihatkan tingkat penyebarannya saja, bukan digunakan untuk menunjukkan tingginya suatu bahaya penyakit.

Virus corona atau covid-19 hadir dalam kehidupan manusia memberikan pengaruh yang sangat luas. pandemi covid-19 telah memaksa Pemerintah dan seluruh elemen masyarakat untuk melakukan perubahan meliputi seluruh sendi kehidupan, tidak terkecuali dibidang pendidikan. Kontruksi model pendidikan berbasis digital merupakan sebuah model yang dapat diterapkan termasuk untuk pendidikan hukum. Dengan tidak mengandalkan pertemuan tatap muka pada ruang kelas dan dosen yang mengajar langsung di hadapan para mahasiswanya, menjadikan digitalisasi sebuah sarana pendidikan yang baru.

Pemindahan pendidikan tatap muka pada ruang kelas ke dalam pendidikan berbasis virtual mengakibatkan seluruh pihak, baik pengajar maupun yang diajar, untuk sebaik mungkin memanfaatkan platform pendidikan yang ada sebagai sarana pembelajaran agar kegiatan belajar mengajar tetap dapat dilaksanakan. ${ }^{1}$

Dalam prosesnya, kegiatan belajar mengajar berbasis virtual ini menjadikan siapapun mau tidak mau harus menerima sistem yang baru dalam dunia pembelajaran. Untuk menghadapi sistem yang baru ini, siapapun dipaksa dan dituntut untuk mempelajari sistem pendidikan baru pada era ini.

Pendayagunaan internet dalam pendidikan bukanlah hal yang baru. Banyak di berbagai negara sudah menggunakan digitalisasi dalam pendidikan. Hanya saja, di Indonesia pada masa sebelum pandemi pendayagunaanya belum optimal.

Sesuai dengan perkembangan teknologi informasi, globalisasi pada era ini pun melaju dengan sangat pesat. Globalisasi telah membawa banyak budaya luar masuk ke

1 Pendidikan di Masa Pandemi, Sudah Efektifkah?. Kompasiana.com. 11 Agustus 2020 00:57. https://www.google.com/amp/s/www.kompasiana.com/amp/kkndr122/5f318a81d541df54ad2cf497/pendidik an-dimasa-pandemi-sudah-efektifkah.

112 Al-Ahwal Al-Syakhsiyyah : Jurnal Hukum dan Peradilan Islam 
Indonesia. Terkecuali media cetak seperti koran dan radio yang telah diawasi oleh pemerintah, teknologi informasi berupa media sosial merupakan media-media yang berkembang tanpa adanya batas antar negara dalam penggunaannya. Atas nama pendidikan, pemerintah mengupayakan peningkatan kualitas serta kuantitas nasional agar dapat siap berkompetisi secara global. Penggunaan internet menjadi bagian yang tak terpisahkan dalam peningkatan kualitas dan kuantitas persaingan global. ${ }^{2}$

Hingga Juli 2019, tercatat jumlah pengguna internet di Indonesia mencapai 171 juta orang. Dari jumlah tersebut, data Global Web Index 2018 menyatakan bahwa 86 persen pengguna internet Indonesia mengoptimalkan internet untuk belanja online.

Dari hasil data tersebut, dapat diketahui bahwa pendayagunaan internet untuk kebutuhan pendidikan masih sangatlah minim. Dengan adanya pandemi covid-19 ini justru mengajarkan bahwa ada banyak hal yang telah terlewatkan dalam kehidupan ini. Salah satunya penggunaan teknologi internet yang seharusnya memberikan dampak positif terutama dalam pendidikan bahkan terabaikan. Dengan tidak dapat dilaksanakannya pendidikan secara tatap muka langsung, menjadikan internet satu-satunya kunci solusi agar pendidikan tetap dapat dilaksanakan selama pandemi ini berlangsung. Menjadikan para mahasiswa maupun dosen dituntut untuk dapat mampu menyesuaikan diri dengan situasi seperti ini serta mengoptimalkan era digitalisasi ini sebagai alat pembelajaran yang mudah serta efektif. Digitalisasi pendidikan ini harus berjalan seefektif mungkin. ${ }^{3}$

\section{METODE PENELITIAN}

Melalui metode kepustakaan yang bertumpu kepada penggunaan referensi pustaka sebagai bahan kajian untuk menggambarkan kerangka teoritis serta wawancara penulisan ini dibuat. Tujuan dari penulisan ini adalah untuk mengetahui apakah metode digitalisasi dapat diterapkan dalam pendidikan hukum serta untuk mengetahui bagaimana kesiapan sarana dan prasarana akademik dalam mendukung sistem digitalisasi pendidikan hukum.

\section{HASIL PENELITIAN DAN PEMBAHASAN}

\section{Pendidikan pada era revolusi industri 4.0}

Revolusi industri telah mengubah pola hidup dan cara kerja manusia secara fundamental. Revolusi industri pada zaman generasi milenial ini mencakup ruang lingkup, skala yang besar, dan kempleksitas yang luas. Perkembangan teknologi yang pesat telah mempengaruhi seluruh disiplin ilmu masuk ke dalam digitalisasi.

2 Pujilestari, Yulita. "Dampak Positif Pembelajaran Online Dalam Sistem Pendidikan Indonesia Pasca Pandemi Covid-19". Volume 4, No. 12020.

${ }^{3}$ Halal Syah Aji, Rizqon. 2020. "Dampak Covid-19 pada Pendidikan di Indonesia: Sekolah, Keterampilan, dan Proses Pembelajaran". Jurnal Sosial dan Budaya Syar-i FSH UIN Syarif Hidayatullah Jakarta. Vol. 7 No. 5. 
Pendidikan era revolusi industri 4.0 merupakan penyesuaian dari kebutuhan revolusi industri akan kurikulum baru yang sesuai dengan situasi keadaan saat ini. Banyak ahli mengemukakan bahwa pendidikan pada era revolusi industri 4.0 ini adalah sebuah gambaran integritas teknologi dalam pembelajaran. Dengan mengoptimalkan fasilitas internet diharapkan mampu membuka jendela dunia pembelajaran dengan lebih mudah.

Pendidikan pada era revolusi industri 4.0 seperti ini memberikan tantangan sendiri bagi tenaga pengajar seperti guru maupun dosen dalam mengimplementasikannya dalam kegiatan belajar mengajar. Sekurang-kurangnya para pengajar diharuskan memiliki 4 kompetensi dalam dirinya, yaitu:

1. Memiliki keterampilan berpikir kritis dalam pemecahan masalah

Keterampilan ini merupakan keterampilan dalam memahami suatu masalah yang sedang terjadi, mencari serta mendapatkan informasi yang diperlukan sebanyak-banyaknya agar kemudian mampu menciptakan berbagai perspektif dalam upaya pemecahan masalah. Dan kompetensi inilah yang kemudian pengajar ajarkan dan implementasikan kepada yang diajarnya.

2. Memiliki keterampilan dalam berkomunikasi dan kolaborasi

Keterampilan ini berkaitan dengan pembelajaran berbasis teknologi informasi, agar pengajar dapat mengoptimalkan keterampilan kolaborasi dalam proses belajar mengajar.

3. Memiliki keterampilan berpikir kreatif serta inovatif

Dalam kegiatan pembelajaran, penting sekali bagi setiap pengajar untuk memiliki jiwa yang kreatif serta inovatif. Sikap ini dapat memicu para mahasiswanya untuk ikut serta dalam berpikir kreatif dan positif dalam menuntut ilmu.

4. Keterampilan literasi teknologi dan informasi

Untuk menjadi pengajar yang berhasil, seseorang harus mampu menggali banyak referensi guna menunjang kegiatan belajar mengajarnya lebih optimal dan tepat.

Era revolusi industri yang serba canggih, membuat keadaan manusia terlena akan hal persaingan yang lebih kuat di setiap bidang kehidupan. Kemudahan dalam mengakses internet dan sumber daya lainnya, membuat persaingan berjalan seperti tak kasat mata. Terutama dalam hal pendidikan, baik pengajar maupun mahasiswa harus mampu dengan bijak mengoptimalkan kuasa internet dalam keseharian. Pemanfaatan internet dengan baik akan menciptakan keberhasilan pada pendidikan di era revolusi industri seperti ini.

a. Pengertian dan Ruang Lingkup Digitalisasi Pendidikan

Digitalisasi pendidikan merupakan pendayagunaan teknologi sebagai aspek dalam sistem pembelajaran, mulai dari kurikulum hingga ke sistem administrasi pendidikan. Perkembangan teknologi saat ini memberikan pengaruh yang sangat besar pada inovasi 
dunia pendidikan. Pemerataan pendidikan pada daerah-daerah terpencil terbantu dengan adanya digitalisasi pendidikan. Digitalisasi pendidikan pun memudahkan para mahasiswa dalam mencari materi secara praktis dan mudah hanya dengan melalui internet, tanpa harus terus menerus menyantap materi dari pertemuan tatap muka secara langsung dengan pengajarnya. Juga bercermin pada dunia saat ini, dimana mahasiswa jauh lebih senang mencari ilmu dengan memanfaatkan gadgetnya daripada membawa buku yang banyak dan tebal-tebal, menjadikan era digitalisasi dalam bidang pendidikan pun semakin berkembang.

Nadiem Makarim sebagai Menteri pendidikan juga memprioritaskan digitalisasi pendidikan ini. Untuk mendapatkan hasil kemajuan dalam hal pendidikan nasional, digitalisasi pendidikan diharapkan mampu membantu para pelaku pendidikan dalam keberlangsungan proses belajar mengajar secara optimal. ${ }^{4}$

Perkembangan era digitalisasi yang pesat ini telah membawa banyak sekali pengaruh pada dunia pendidikan. Dahulu, dimana dalam proses pendidikan hanya mengandalkan seorang guru saja sebagai sumber informasi. Kini hadir internet, yang dapat dengan mudah kita akses untuk mendapatkan informasi yang kita butuhkan. Dengan digitalisasi pendidikan ini diharapkan pengajar mampu mengembangkan visualisasi yang diajar melalui komputer sebagai media terhadap materi yang disampaikan.

Perkembangan teknologi yang sangat pesat memberikan dampak perubahan pada pendidikan. Hal tersebut dapat dirasakan saat mengakses informasi dari internet. Kemudahan yang didapatkan dalam mengakses informasi dalam internet membuat internet ini sebagai suatu hal yang digemari oleh semua kalangan. ${ }^{5}$

Saat ini masyarakat sangat bergantung pada teknologi informasi. Terlebih era saat ini merupakan era milenial dimana para pemudanya sangat canggih akibat hidup dalam perkembangan teknologi yang sangat pesat. Menjadikan teknologi informasi ini harus dioptimalkan dalam keseharian, terutama dalam pendidikan.

Dengan mengikuti perkembangan zaman, digitalisasi pendidikan ini dihadirkan. Dengan maksud agar pendidikan tetap dapat menghasilkan pembelajaran yang sesuai dengan arah dan tujuannya. Mengelola digitalisasi dengan cerdas dan tepat merupakan tantangan baru dalam dunia pendidikan agar kegiatan pembelajaran tetap dapat dilaksanakan.

Ada banyak sekali manfaat yang didapatkan dari digitalisasi pendidikan ini, yaitu proses belajar mengajar tidak terbatas waktu, kapasitas daya tampung tidak terbatas karena pembelajaran tidak dilakukan di dalam kelas yang terbatas areanya, serta jangka

\footnotetext{
${ }^{4}$ Zikrillah, “Digitalisasi Pendidikan Zaman Now”, Kompasiana, 3 Desember 2019.

${ }^{5}$ Ahmad Tosepu, Yusrin. 2018. “ Digitalisasi Pendidikan (Telaah Dunia Pendidikan menuju Transformasi Digital) ". yusrintosepu.wixsite.com/yoes
} 
waktu pembelajaran dalam masa digitaslisasi pendidikan inipun tergantung pada tiap tiap pelaku pendidikan.

Pendidikan yang baik merupakan pendidikan yang mampu mengoptimalkan dan memahami perkembangan keadaan sekitarnya dan menyesuaikan sesuai dengan yang dibutuhkan. Penting adanya intuisi pendidikan yang tinggi untuk dapat membekali mahasiswa memiliki keahlian yang tepat untuk memenuhi tuntutan dimasa yang akan datang.

Ruang lingkup digitalisasi pendidikan sendiri ialah pemanfaatan, pengelolaan, pengembangan, penilaian serta lingkup bentuk pembelajaran. Pemanfaatan itu sendiri ialah pengoptimalan dalam proses pembelajaran dan aktivitas penggunaan sumber untuk pembelajaran. Hal ini berkaitan antara para pelaku pendidikan dengan bahan serta sistem pendidikan yang ada.

Pengelolaan, merupakan pengendalian teknologi digitalisasi pendidikan melalui proses pengorganisasian, perencanaan serta visi penididikan. Seperti dengan mengadakan program-program media sekolah sebagai pembaharuan pendidikan.

Pengembangan merupakan proses bentuk pembelajaran yang lebih kompleks dalam bentuk fisik meliputi teknologi visual, cetak serta berbasis komputer. Penilaian ${ }^{6}$ ialah proses menilai terhadap kegiatan pembelajaran apakah memadai atau tidaknya. Dan yang terakhir ialah, lingkup bentuk pembelajaran. Ialah sebuah proses untuk menentukan situasi kegiatan belajar mengajar dengan menyiapkan strategi pembelajaran yang paling tepat.

Pendidikan menempati posisi peranan yang sangat penting dalam upaya menciptakan kehidupan bangsa yang cerdas dan maju. Pendidikan memiliki peran yang sangat penting dalam penanaman dan pengembangan nilai-nilai yang ada dalam diri masyarakat. Untuk dapat meraih sebuah kedudukan dan kinerja yang baik, pendidikan sangat penting untuk didapatkan.

Dalam Undang-undang Nomor 20 Tahun 2003 tentang Sistem Pendidikan Nasional, di dalamnya dijelaskan dasar serta tujuan penyelenggaraan pendidikan dalam kehidupan. Kegiatan wajib belajar untuk menjamin kualitas masyarakatnya dalam sistem pendidikan nasional.

\section{b. Tantangan Digitalisasi Pendidikan}

Di masa pandemi seperti ini, merupakan wajah baru dalam sistem dunia pendidikan negara republik Indonesia. Wabah penyakit yang cepat sekali menyebar, membuat seluruh kegiatan dan interaksi langsung antar manusia dibatasi, salah satunya pada lembaga pendidikan. Sekolah sekolah hingga universitas ditutup dan kegiatan

${ }^{6}$ Piopiunik, M, G Schwerdt, L Simon and L Woessman, 2020, Skill, signals and employability: An experimental investigation. Europan Economic Review 123: 103374.

116 Al-Ahwal Al-Syakhsiyyah : Jurnal Hukum dan Peradilan Islam 
belajar mengajar dilakukan didalam rumah secara online. Kegiatan belajar mengajar tanpa tatap muka langsung seperti inilah yang merupakan menjadi kebiasaan baru yang jauh dari kebiasaan pada umumnya saat virus corona belum mewabah.

Hal ini membuat para pelaku pendidikan mendapatkan tantangan baru dalam belajar agar dapat maksimal dalam pelaksanaannya. Para pelaku pendidikan khususnya para pengajar berjuang sekuat mungkin untuk menetapkan dan menciptakan strategistrategi yang tepat untuk kegiatan pembelajaran yang efektif serta efisien. Karena sekalipun kontak fisik dibatasi, namun pendidikan harus tetap berlanjut dalam situasi apapun. Sebagai pengajar harus tetap menjalankan amanat yang terkandung dalam Undang-undang Nomor 14 Tahun 2005 Tentang Guru dan Dosen Pasal 1 Ayat 1 untuk tetap mendidik, mengarahkan, melatih serta mengevaluasi yang dididiknya.

Menciptakan strategi yang kreatif dan inovatif dalam kegiatan belajar mengajar ${ }^{7}$, sangat memberikan pengaruh besar pada semangat para peserta didik dalam dibina dan diarahkan. Ditengah kondisi harus selalu dirumah, pembelajaran menggunakan media yang tepat serta penyampaian materi yang menarik juga dapat membuat para peserta didik semangat dalam kegiatan belajar mengajar.

Pemanfaatan media informasi dan komunikasi yang benar juga perlu diperhatikan bagi setiap peserta didik dalam menggali informasi. Fasilitas internet yang telah memadai seharusnya dapat mempermudah para peserta didik dalam memperoleh ilmu dan menjadi generasi yang maju bagi bangsa.

Adapun sebagian peserta didik yang mendapati kendala dalam kegiatan pembelajaran online ini. Minimnya sinyal karena tinggal di daerah pelosok serta tidak adanya fasilitas gadget untuk belajar menjadikan sebagian peserta didik berusaha keras dalam meraih pendidikan di era digitalisasi pendidikan ini. Saat ini pun pemerintah menyediakan fasilitas kuota gratis untuk menunjang kegiatan belajar mengajar ini dapat dilaksanakan dengan baik dan tanpa kendala. Sejumlah kelurahan pun mengadakan patungan bagi tiap-tiap warganya untuk menyediakan fasilitas wifi bagi keberlangsungan digitalisasi pendidikan.

Saat ini pun terdapat istilah guru keliling, yang fungsinya untuk berkeliling melayani para peserta didik yang tidak bisa mengakses kegiatan belajar mengajar secara online. Hal ini sebagai bentuk totalitas para pengajar dalam menjalankan amanat tugasnya terhadap terlayaninya peserta didik dalam menunjang pendidikannya.

c. Kesiapan Sarana dan Prasarana Akademik dalam Mendukung Digitalisasi Pendidikan Hukum

\footnotetext{
${ }^{7}$ Mustawan, Agus. 10 Juli 2020. "Pendidikan di Masa Pandemi, Hambatan atau Peluang Transisi Model Belajar?". https://kuninganmass.com/govermment/education/pendidikan-di-masa-pandemi-hambatan-ataupeluang-transisi-model-belajar/.
} 
Melalui kebijakan-kebijakannya, pemerintah berupaya meningkatkan kembali kualitas layanan instuisi pendidikan yang diberikan kepada masyarakat terutama para pelaku pendidikan. Upaya tersebut berupa perluasan akses layanan pendidikan, standar nasional pendidikan, perbaikan sarana dan prasarana. Standar nasional ini berfungsi sebagai dasar dalam menciptakan pendidikan nasional yang lebih berkualitas lagi.

Lingkup standar nasional pendidikan ialah standar sarana dan prasarana. Seperti peralatan pendidikan, buku, sumber belajar, dan media pembelajaran merupakan sarana pendidikan yang harus dimiliki untuk menunjang proses kegiatan belajar mengajar.

Sedangkan prasarana yang harus dimiliki sebagai penunjang proses kegiatan belajar mengajar ialah berupa ruang kelas, ruang pengajar, perpustakaan, kantin serta tempat tempat penunjang pendidikan lainnya.

Namun dalam situasi pandemi seperti ini, maka sarana dan prasarana yang dibutuhkan ialah gadget sebagai alat untuk berkomunikasi dan meraih sumber informasi. Serta aplikasi program pendidikan dan jaringan teknologi internet.

Aplikasi program pendidikan seperti Ruang Guru dan lainnya, berperan penting pada saat seperti ini sebagai media yang membantu menghubungkan peran guru serta orang tua dalam membangun masa depan para peserta didik yang lebih berkualitas lagi. Karena kemajuan pendidikan merupakan tugas dan tanggung jawab bersama sebuah bangsa. Apapun kendalanya, pendidikan sebuah bangsa harus tetap dilanjutkan dan dikembangkan kapanpun dan di mana pun.

Jaringan teknologi internet yang merupakan sebagai sebuah sumber informasi dalam kegiatan pembelajaran, penting sekali untuk dimiliki dan tersedia fasilitasnya. Melihat pada era ini internet sangat berperan penting bagi kebutuhan informasi, sebagai penunjang materi pembelajaran internet sangat ramai digunakan oleh setiap pelaku pendidikan baik guru, dosen, maupun siswa dan mahasiswa.

Untuk menunjang pendidikan bagi yang kurang mampu, pihak sekolah memiliki Surat Keputusan (SK) peserta didik yang kurang mampu dan mendapatkan subsidi silang serta dilakukan pendampingan bejalar bagi peserta didik yang telah didata. ${ }^{8}$

Dekan Fakultas Hukum, Kelik Endro Suryono, SH., M.Hum mengatakan bahwa dikala pandemi seperti ini, kualitas pendidikan hukum akan terjaga dengan baik apabila tiga aspek diperhatikan. Yaitu intuisi pendidikan dosen dan mahasiswa, regulasi serta infrastruktur, dan pengawasan. ${ }^{9}$ Dosen maupun mahasiswa harus mengoptimalkan media internet sebagai penunjang pendidikan.

8 Gugah Asih, Shintya. 2020. "Pendidikan Era Revolusi Industri 4.0 di Tengah Covid-19". https://ombudsman.go.id/artikel/r/artikel--pendidikan-era-revolusi-industri-40-di-tengah-covid-19

9 HumasWidyaMataram. 2020. "Sharing Corner 3: Menjaga Kualitas Pendidikan di Tengah Pandemi". http://new.widyamataram.ac.id/content/news/sharing-corner-3-menjaga-kualitas-pendidikan-di-tengahpandemi\#.X2x4jTkxc0M.

118 Al-Ahwal Al-Syakhsiyyah : Jurnal Hukum dan Peradilan Islam 
Pada akhirnya, ditengah mewabahnya virus covid-19, digitalisasi pada era revolusi industri 4.0 ini tetap dapat dilaksanakan dengan penyesuaian sarana dan prasarana terhadap kondisi saat ini tanpa menyampingkan dampak dampak yang timbul setelahnya. Peserta didik dituntut untuk memiliki peran dalam membawa perubahan positif dimasa pandemi covid-19 berdasarkan pemahaman dan ilmu yang telah diberikan oleh pengajar.

\section{KESIMPULAN}

Dewasa ini dunia digemparkan oleh suatu peristiwa wabah penyakit yang dapat mematikan banyak dari umat manusia dalam rentan waktu yang amat singkat. Penyakit yang bermula dari sebuah virus bernama corona atau disebut dengan istilah covid-19 ini mulai mewabah pada akhir bulan Desember tahun 2019 lalu di Kota Wuhan Provinsi Hubei Tiongkok, yang kemudian mewabah hingga ke seluruh dunia dalam rentan waktu yang amat singkat. Hingga pada tanggal 11 Maret 2020 WHO (World Health Organization) menetapkan wabah virus ini sebagai pandemi global.

Virus corona atau covid-19 hadir dalam kehidupan manusia memberikan pengaruh yang sangat luas. pandemi covid-19 telah memaksa Pemerintah dan seluruh elemen masyarakat untuk melakukan perubahan meliputi seluruh sendi kehidupan, tidak terkecuali dibidang pendidikan. Kontruksi model pendidikan berbasis digital merupakan sebuah model yang dapat diterapkan termasuk untuk pendidikan hukum. Dengan tidak mengandalkan pertemuan tatap muka pada ruang kelas dan dosen yang mengajar langsung dihadapan para mahasiswanya, menjadikan digiitalisasi sebuah sarana pendidikan yang baru.

Digitalisasi pendidikan merupakan pendayagunaan teknologi sebagai aspek dalam sistem pembelajaran, mulai dari kurikulum hingga ke sistem administrasi pendidikan. Dengan hidup di era revolusi industri 4.0, menjadikan digitalisasi merupakan sistem pendidikan yang tepat sebagai satu-satunya solusi agar pendidikan bangsa Indonesia ini tetap berjalan pada masa pandemi covid-19.

Pendidikan era revolusi industri 4.0 merupakan penyesuaian dari kebutuhan revolusi industri akan kurikulum baru yang sesuai dengan situasi keadaan saat ini. Banyak ahli mengemukakan bahwa pendidikan pada era revolusi industri 4.0 ini adalah sebuah gambaran integritas teknologi dalam pembelajaran. Dengan mengoptimalkan fasilitas internet diharapkan mampu membuka jendela dunia pembelajaran dengan lebih mudah.

Digitalisasi pendidikan menciptakan sebuah tantangan baru bagi para pelaku pendidikan, terutama bagi para pengajar. Para pengajar berjuang sekuat mungkin untuk menetapkan dan menciptakan strategi-strategi yang tepat untuk kegiatan pembelajaran yang efektif serta efisien. Sebagai pengajar harus tetap menjalankan amanat yang 
terkandung dalam Undang-Undang No 14 Tahun 2005 Tentang Guru dan Dosen pasal 1 ayat 1 untuk tetap mendidik, mengarahkan, melatih serta mengevaluasi yang dididiknya. Karena sekalipun kontak fisik dibatasi, namun pendidikan harus tetap berlanjut bagaimanapun situasinya.

Diperlukan kesiapan sarana dan prasarana akademik dalam mendukung digitalisasi pendidikan hukum berupa gadget sebagai alat untuk berkomunikasi dan meraih sumber informasi. Serta aplikasi program pendidikan dan jaringan teknologi internet.

Jaringan teknologi internet yang merupakan sebagai sebuah sumber informasi dalam kegiatan pembelajaran, penting sekali untuk dimiliki dan tersedia fasilitasnya. Melihat pada era ini internet sangat berperan penting bagi kebutuhan informasi, sebagai penunjang materi pembelajaran internet sangat ramai digunakan oleh setiap pelaku pendidikan baik guru, dosen, maupun siswa dan mahasiswa. Bagi yang terkendala jaringan internet serta gadget, Pemerintah menyediakan fasilitas kuota gratis bagi yang membutuhkan serta terdapat guru keliling, yang fungsinya untuk berkeliling melayani para peserta didik yang tidak bisa mengakses kegiatan belajar mengajar secara online.

Pada akhirnya, ditengah mewabahnya virus covid-19, digitalisasi pendidikan pada era revolusi industri 4.0 ini tetap dapat dilaksanakan dengan penyesuaian sarana dan prasarana terhadap kondisi saat ini tanpa mempersulit atas kendala-kendala yang hadir.

\section{DAFTAR PUSTAKA}

Ahmad Tosepu, Yusrin. 2018. " Digitalisasi Pendidikan(Telaah Dunia Pendidikan menuju Transformasi Digital) ". yusrintosepu.wixsite.com/yoes

Gugah Asih, Shintya. 2020. "Pendidikan Era Revolusi Industri 4.0 di Tengah Covid-19". https://ombudsman.go.id/artikel/r/artikel--pendidikan -era-revolusi-industri-40-ditengah-covid-19

Halal Syah Aji, Rizqon. 2020. "Dampak Covid-19 pada Pendidikan di Indonesia: Sekolah, Keterampilan, dan Proses Pembelajaran". Jurnal Sosial dan Budaya Syar-i FSH UIN Syarif Hidayatullah Jakarta. Vol. 7 No. 5.

HumasWidyaMataram. 2020. "Sharing Corner 3: Menjaga Kualitas Pendidikan di Tengah

Pandemi". http://new.widyamataram.ac.id/content/news/sharing-corner-3-menjagakualitas-pendidikan-di-tengah-pandemi\#.X2x4jTkxc0M.

Mustawan, Agus. 10 Juli 2020. "Pendidikan di Masa Pandemi, Hambatan atau Peluang Transisi Model Belajar?". https://kuninganmass.com/govermment/education/pendidikan-dimasa-pandemi-hambatan-atau-peluang-transisi-model-belajar/.

Pendidikan di Masa Pandemi, Sudah Efektifkah?. Kompasiana.com. 11 Agustus 2020 00:57. https://www.google.com/amp/s/www.kompasiana.com/amp/kkndr122/5f318a81d5 $\underline{\text { 41df54ad2cf497/pendidikan-dimasa-pandemi-sudah-efektifkah. }}$ 
Dian Rachmat G, Sri Shopiarani D, Revitalisasi Pendidikan Hukumdan Prospeknya Pasca Pandemi

Piopiunik, M, G Schwerdt, L Simon and L Woessman, 2020, Skill, signals and employability: An experimental investigation. Europan Economic Review 123: 103374.

Pujilestari, Yulita. "Dampak Positif Pembelajaran Online Dalam Sistem Pendidikan Indonesia Pasca Pandemi Covid-19". Volume 4, No. 12020. 
Volume I, Nomor 2, September 2020

[Halaman ini sengaja dikosongkan]

122 Al-Ahwal Al-Syakhsiyyah : Jurnal Hukum dan Peradilan Islam 